\title{
28 Research Square \\ Drought and the Changing Pattern in Sheep Breeds in Sokoto-Rima River Basin, Nigeria
}

Joseph Omoniyi Adejuwon ( $\sim$ adejoseph2003@yahoo.com )

Department of Water Resources Management and Agrometeorology Federal University of Agriculture

Research

Keywords: drought, changing Pattern, sheep breeds, Africa

Posted Date: November 1st, 2021

DOI: https://doi.org/10.21203/rs.3.rs-1021119/v1

License: (a) (i) This work is licensed under a Creative Commons Attribution 4.0 International License. Read Full License 


\section{Abstract}

Drought is a global environmental hazard that impacts livestock production adversely. It is a major problem in the Sokoto-Rima River Basin (Semi-arid agro-ecological zone), Nigeria. However, existing literature suffers a knowledge gap on the effect of drought on the changing pattern in sheep breeds. The cluster sampling technique was used to administer the questionnaire to 450 farmers who were sampled from 15 agricultural settlements in fifteen local governments in the basin. Data were analysed using qualitative methods and the Standardised Precipitation Index. Farmers and quantitative reasoning confirmed the frequency, severity, and extremity of drought on sheep. The drought accounted for $56.67 \%$ of all rainfall anomalies. Four breeds of sheep were discovered, while responses showed that more than half of the farmers in the basin reared sheep, and single breed accounted for over three-quarters of breeds. Balami was the most reared sheep breed and 4.44\%, 7.26\%, and 32.26\% more than Yankasa, Uda, and Hausawa, respectively. This breed with Uda was more reared than other combined sheep breed. Most farmers changed breed due to drought effect, with half of them formerly rearing Yankasa. Farmers were affected in the range of one to five drought impacts. The size reduction was the greatest consequence of drought on sheep while death of sheep, reduction in offspring and milk yield, and infertility in rams were also important. Understanding drought characteristics, its' effect on changing of sheep breed, and the nature of drought impact on sheep will aid drought planning. This paper makes recommendations for mitigation and management strategies in Sokoto-Rima River Basin.

\section{Introduction}

Sheep (Ovis aries) are quadrupedal, ruminant mammals typically kept as livestock. Like all ruminants, sheep are members of the order Artiodactyla, the even-toed ungulates (Theodor, 2001; Mooney and Zavaleta, 2016). Although the name "sheep" applies to many species, in everyday usage it almost always refers to Ovis aries. Domestic sheep are more than one billion and are the most abundant species in their genus (The Editors of Encyclopaedia Britannica, 2020). Sheep are most likely descended from the wild mouflon of Europe and Asia. One of the earliest animals to be domesticated for agricultural purposes, sheep were raised for fleece, meat (lamb, hogget, or mutton), and milk. Domestication of wild sheep took place in Mesopotamia in the Middle East in Central Asia, in present-day Turkey, Iraq, Syria, Jordan, Lebanon, and Israel. Findings of bones of sheep date back to the Neolithic or New Stone Age $(10,000-$ 8,000 B.C.) (Budiansky, 1999; Hiendleder et al., 2002). Sheep entered the African continent not long after their domestication in western Asia. The first sheep entered North Africa via Sinai and were present in ancient Egyptian society between eight and seven thousand years ago. Sheep have always been part of subsistence farming in Africa, but today, South Africa is the only country that keeps an influential number of commercial sheep (Blench and MacDonald, 1999).

There are four breeds of sheep native to Nigeria namely Yankasa, Uda, Balami, and West African Dwarf (WAD) (Adu and Ngere, 1979; RIM, 1992). These sheep are closely related and are generally considered a variety of a breed designated 'Fulani' (Mason, 1988). The Balami is the largest-bodied native sheep in 
Nigeria. Sheep are kept everywhere in Nigeria. Sheep are kept both in villages and by pastoralists. While Yankasa, Uda, Balami are more common in the north, the WAD is more common in the south.

Sheep is one of the livestock species that serves as the main source of livelihood for livestock farmers in Nigeria. They reproduce and multiply fast and are easily convertible to cash to meet the financial needs of the farmers including agricultural inputs, school fees, and so on. Sheep are assets that need low initial investment with fast profits due to quick reproduction (Amankwah et al., 2012). However, the many contributions of sheep to rural society are being challenged by drought most especially in the arid and semi-arid environments. Sheep is susceptible to abortion, the birth of under-sized weak lambs, and outbreaks of diseases such as coccidiosis, enterotoxaemia, pregnancy toxemia, and so on during drought due to stress and dietary problems (Chedid et al., 2014; Leite-Browning, 2016).

Previous studies on the effect of drought on sheep in the semi-arid agroecological zones of tropical Africa include Devereux et al. (1993), Alary et al. (2014), Catley et al., 2014; Oyekale, 2014; Ahmed et al., 2019), Devereux et al. (1993) examined the socio-economic impact of the 1992/93 drought on households in Namibia. Alary et al. (2014), assessed the livelihood strategies and the role of livestock in the processes of adaptation to drought in the Coastal Zone of Western Desert (Egypt). Catley et al., 2014 examied the livestock mortality in pastoralist herds in Ethiopia and implications for drought response. Oyekale (2014) studied the impacts of climate change on livestock husbandry and adaptation options in the arid Sahel belt of West Africa: evidence from a baseline survey. Ahmed et al. (2019) studied the economic burden of livestock disease and drought in Northern Tanzania.

Despite these studies and the fact that the impacts of drought remain a serious challenge, no study exists on the effect of drought on the changing pattern in sheep breeds in the semi-arid agro-ecological zone of Nigeria. This study fills the gap created by insufficient literature on drought on the changing pattern in sheep breeds in the zone. The objectives of the study include: the characterization of drought in the study area; assessment of sheep breeds and changes in sheep breeds over time in the study area; examination of the nature of the drought impact on sheep in the study area

\section{Methodology}

\subsection{Study Area}

The study area, Sokoto-Rima River Basin which lies between latitude $10.8^{\circ} \mathrm{N}$ and $13.58^{\circ} \mathrm{N}$ and longitude $3.30^{\circ} \mathrm{E}$ and $7.13^{\circ} \mathrm{E}$ (Figures $1 \mathrm{a}$ and $\mathrm{1b}$ ) exhibits a tropical climate with a definite and marked wet and dry season. The tropical maritime air mass from the Atlantic Ocean dominates the entire basin during the wet season while the tropical continental (CT) air mass from the Sahara Desert predominates during the dry season. Rain falls when the $\mathrm{mT}$ air mass dominates an area while dryness predominates when $\mathrm{cT}$ prevails. The wet season is between May/June to September while the dry season make-up the remaining part of the year (Adejuwon, 2015). The rainfall pattern in the study area is a good reflection of the seasonal variation of the surface location of the inter-tropical discontinuity (ITD). Annual rainfall 
amounts varied from $1013 \mathrm{~mm}$ in the south to $650 \mathrm{~mm}$ in the north while high temperatures are experienced all year round with the mean annual temperature of $34.5^{\circ} \mathrm{C}$ (Adejuwon, 2019). The rainfall is single maxima in character and decreases in both duration and amount from the south northward. The highest temperatures occur from March to April while the minimum temperatures are recorded in January to February. High humidity reaching an average of $80 \%$ in the southern area during the wet season is experienced in the wet season and lower humidity of about $30 \%$ in the dry season (Oboli, 1967; Emielu, 2000). The dry and dust-laden northeast trade wind called 'Harmattan' is accompanied by very low temperatures and thick fog blows from the Sahara Desert under cloudless but dusty conditions from November to February (Adejuwon, 2016).

\subsection{Data Collection}

The data employed for this study were sourced from archival records and field investigations. Monthly rainfall data for Sokoto, Gusau, and Kebbi States in Sokoto-Rima River Basin, Nigeria from the period 1970 to 2009 were retrieved from the archives of the Nigeria Meteorological Agency (NIMET), Abuja, Nigeria. NIMET observers used the British standard dines titling siphon rain gauge rainfall recorder to record the data in these stations. The stations were not affected by site relocation and there was no missing data. For field investigation, the cluster sampling technique was used to administer the questionnaire to 450 farmers who were sampled from 15 agricultural settlements in fifteen local governments in the basin (Table 1). The questionnaire was complete because each of the respondents was interviewed based on the structured questionnaire. Pre-computation and post-computation checks were carried out on the data. 
Table 1

Locations of primary data collection in the Sokoto-Rima River Basin

\begin{tabular}{|l|}
\hline State Local Government Community \\
\hline Sokoto Wamakko Gumbi \\
Dodinga Mil Goma \\
Kware Durbawa \\
Rabah Maikujera \\
Kebbi Kalgo Kalgo \\
Birni-Kebbi Gulumbe \\
Aliero Dakala \\
Jega Basaura \\
Argungu Alwasa \\
Zamfara Talata Mafara Tunfafiya \\
Gusau Madidi \\
Maradun Dosara \\
Bungudu Tazame \\
Tsafe Tsafe
\end{tabular}

\subsection{Data Analysis}

Data were analyzed using Statistical Package for Social Sciences (SPSS 17) with descriptive statistics (frequency counts and percentages) and Standardized Precipitation Index (SPI).

The following procedure was followed for SPI:

1. Calculate the long-term mean and standard deviation over the study period for each station.

2. Calculate SPI values for each year over the study period.

3. Then calculate drought occurrence, duration, and intensity.

The SPI calculation is based on the long-term precipitation record for the chosen period in a particular place. Edwards and McKee (1997) joined the long-term record into a probability distribution and later changed it into a normal distribution so that the average SPI for the location and chosen period is zero. The positive SPI values specify more than normal precipitation while the negative values show less than normal precipitation. The SPI forms a good representation of wetter and drier climates since it is normalized. A drought event occurs any time the SPI is continuously negative and reaches an intensity of 
- 1.0 or less with expiration at zero - a positive sign (Table 2). The SPI for each station was determined using the equation below:

Table 2

Standardized Precipitation Index

Values and Categories

(Adapted from McKee et al., 1993)

\begin{tabular}{|ll|}
\hline SPI Values & Categories \\
\hline $2.0+$ & extremely wet \\
\hline 1.5 to 1.99 & very wet \\
\hline 1.0 to 1.49 & moderately wet \\
\hline-0.99 to 0.99 & near normal \\
\hline-1.0 to -1.49 & moderately dry \\
\hline-1.5 to -1.99 & severely dry \\
\hline-2 and less & extremely dry \\
\hline
\end{tabular}

SPI $1 / 4$ ðXik-Xip= $\sigma i$

where $\sigma i$ = standardized deviation for the ith station, Xik = rainfall for the ith station and kth observation, and $\mathrm{Xi}=$ mean rainfall for the ith station. All negative SPI values show drought occurrence, while all positive values show no drought.

Drought indices have been widely used in assessing, monitoring, and forecasting drought globally. These include the Palmer Drought Severity Index (PDSI) (Palmer, 1965), Decile Index (DI) (Gibbs and Maher, 1967), Standardized Precipitation Index (SPI) (McKee et al. 1993), Percent of Normal Index (PNI) (Willeke et al., 1994), China-Z Index (CZI) (Wu et al., 2001), among others. The SPI is preferred to other indices and used in this study. Salmoral et al. (2020) reported that the SPI has been applied and proved useful as a drought index. Its merits include flexibility, multipurpose, ability to assess drought severity, spatial consistency, and less complexity than many other drought indices including the Palmer Drought Severity Index (PDSI) (McKee et al. 1993; Adejuwon and Olaniyan, 2019). It is also excellent for the decisionmaking process due to its probabilistic nature, has multi-timescale features, comparable across regions, the qualities the PDSI lacked (World Meteorological Organization 2012; Dai and National Center for Atmospheric Research Staff, 2017).

\section{Result And Discussion}

\subsection{Drought occurrence in the study area}


Drought events of different categories, ranging from mild (55.88\%) to extreme (2.94\%) characterized more than half of the 40 years studied in most of the stations in Sokoto-Rima River Basin (Figure 2a-c). The study revealed 19 to 25 years of droughts events in the stations totaling 68 of the total 120 years (56.67\%). Mild drought was more common at Yelwa (21 times) than other stations, while Gusau with 12 times of moderate drought occurrence experienced the highest number of moderate drought events. The drought was severe at Sokoto in 1973 and Gusau in 1987 but extreme at Sokoto in 1987 and Yelwa in 2007. The severe and extreme droughts were the most destructive to agriculture and the cause of setbacks for the economy (Adejuwon and Olaniyan, 2019). Mijiindadi and Adegbehin (1991) reported that the impact of the 1972/73 drought on livestock such as sheep, cattle, and goats was very severe and that entire northern Nigeria lost between 1.5-1.8 million livestock which is about $20 \%$ of Nigeria total livestock population. The duration of drought varied from 1 to 8 years in the study area, with 1 to 5 years, 1 to 4 years, and 1 to 8 years for Sokoto, Yelwa, and Gusau respectively. The extension of drought for a long period decapacitates sheep production as a result of the inability to regain. For instance, the extensive drought that ravaged Australia from 1895-1903, 1911-1916, 1942-1945, and 1963-1968 resulted in 53 million (50\%), 19 million, 30 million, and 20 million sheep deaths respectively (ABARES, 2011).

\subsection{Sheep breeds in the study Area}

As shown in Table 3, four breeds of sheep reared in the Sokoto-Rima River Basin include Yankasa, Uda, Balami, and Hausawa. However, earlier studies identified three sheep breeds namely Yankasa, Uda, and Balami (designated 'Fulani)' in this area (Mason, 1988, RIM, 1992). The emergence of Hausawa was a recent development in the River Basin. Fifty-five percent (55.1\%) of the farmers in the basin reared sheep. The sheep were better reared as a single breed since $77.86 \%$ of the sheep herders reared a single of sheep. Yankasa constituted $30.24 \%$ of the single breed. The multiple breeds include three breeds Yankasa, Uda and Balami (8.06\%) and two breeds - Yankasa and Uda, Balami and Hausawa, and Uda and Balami which ranged from $0.81-12.1 \%$ respectively. 
Table 3

Breed of Sheep reared in Sokoto-Rima River Basin

\begin{tabular}{|llll|}
\hline S/N & Sheep Breed & Number of respondents & Percentage (\%) \\
\hline 1 & Yankasa only & 75 & 30.24 \\
\hline 2 & Uda only & 38 & 15.32 \\
\hline 3 & Balami only & 55 & 22.18 \\
\hline 4 & Hausawa only & 25 & 10.08 \\
\hline 5 & Yankasa/Uda & 2 & 0.81 \\
\hline 6 & Yankasa/Uda/Balami & 20 & 8.06 \\
\hline 7 & Uda/Balami & 30 & 12.1 \\
\hline 8 & Balami/Hausawa & 3 & 1.21 \\
\hline & Total & $248(55.1 \%)$ & 100 \\
\hline
\end{tabular}

In totality, Balami (43.55\%) was mostly reared (Table 4). This contradicts the earlier report of RIM (1992) which reported that Yankasa was the most common sheep breed in this area, but Uda and Balami breeds were also kept. Balami was 4.44\% more than Yankasa, 7.26\% more than Uda and 32.26\% more than Hausawa. The shift from Yankasa to Balami could have been because Balami was larger-bodied and more productive. It is the largest-bodied native sheep in Sokoto-Rima River Basin. RIM (1992) reported that the Balami stands out from the other breeds because it was more prolific than Uda, and Yankasa. RIM also noted that Uda was more productive than the Yankasa. This could have been the reason why pastoralist herds often consist of Balami and Uda. The farmers noted that Hausawa, a new breed of sheep in the River Basin emerged as a result of cross-breed between Yankasa and Uda. The total number of Hausawa reared showed that the breed was not widely reared like the other breeds at the period of this investigation, but was gaining recognition and spreading fast among the farmers. There is a possibility of the breed becoming the most reared breed in the nearest future.

Table 4

The total breed of Sheep reared in Sokoto-Rima River Basin

\begin{tabular}{|llll|}
\hline S/N & Sheep Breed & Number of respondents & Percentage (\%) \\
\hline 1 & Yankasa & 97 & 39.11 \\
2 & Uda & 90 & 36.29 \\
3 & Balami & 108 & 43.55 \\
4 & Hausawa & 28 & 11.29 \\
\hline
\end{tabular}

\subsection{Changes in Sheep Breeds in the study area}


When farmers were asked whether they changed their sheep breed, responses showed that $33.06 \%$ of the farmers' changed their sheep breed (Table 5). This indicates that one-third of the sheepherders in the basin changed breed. Sixteen percent $(15.73 \%)$ of the herders reared Yankasa only while others reared Uda only, Balami only, Yankasa and Uda together as well as Yankasa and Balami together (Table 6). The farmers that attributed the change to drought were $30.65 \%$. In totality, $17.75 \%$ and $10.86 \%$ of the farmers changed from the rearing of Yankasa, and Uda respectively to Balami (Table 7). This shows that the change of other breeds to Balami constituted $81.53 \%$ of the entire breeds.

Table 5

Farmers that reared the same sheep breed or changed breed in Sokoto-Rima River Basin

\begin{tabular}{|llll|}
\hline S/N & Sheep breed & Number of Respondents & Percentage \\
\hline 1 & Reared the same breed of sheep & 125 & 50.41 \\
\hline 2 & Change breed & 82 & 33.06 \\
\hline 3 & Did not rear sheep in the past & 41 & 16.53 \\
\hline Total & & 248 & 100 \\
\hline
\end{tabular}

Table 6

A change in sheep breed over time in the Sokoto-Rima River Basin

\begin{tabular}{|llll|}
\hline S/N & Sheep Breed & Number of respondents & Percentage (\%) \\
\hline 1 & Yankasa only & 39 & 15.73 \\
\hline 2 & Uda only & 23 & 9.27 \\
\hline 3 & Balami only & 15 & 6.05 \\
\hline 4 & Yankasa/Balami & 2 & 0.81 \\
\hline 5 & Yankasa/Uda & 3 & 1.21 \\
\hline & Total & 82 & 33.06 \\
\hline
\end{tabular}

Table 7

Total change in sheep breed over time in the Sokoto-Rima River

Basin

\begin{tabular}{|llll|}
\hline S/N & Sheep Breed & Number of respondents & Percentage (\%) \\
\hline 1 & Yankasa & 44 & 17.75 \\
\hline 2 & Uda & 26 & 10.48 \\
\hline 3 & Balami & 17 & 6.86 \\
\hline
\end{tabular}

Most farmers (98.6\%) noted that the climate is changing and that droughts affected sheep rearing. Jones (2014) reported that drought is a frequent event that critically affects the productivity of sheep and 
that the nutritional status is the most important factor in this regard. Nutrition exerts a very large influence on flock reproduction, milk production, and lamb growth (Jones, 2014). Deficiencies, excesses, and imbalances of vitamins and minerals can limit animal performance and lead to various health problems. Fiber is necessary to maintain a healthy rumen environment and prevent digestive upsets while hay tends to be a moderate source of protein and energy for sheep. Legume hays including alfalfa, clover, and so on tend to be higher in protein, vitamins, and minerals, especially calcium, than grass hays. The decreased water availability during the drought period leads to a reduction in hays and other diets.

\subsection{The nature of drought impact on Sheep in the study Area}

The nature of the drought impact on sheep includes the death of sheep, reduction in offspring (calving), reduction in milk yield, infertility in male sheep (Ram), size reduction, and disease. The nature of the drought impact varied from 1 to 3 for most of the farmers, and 4 to 5 for some (Table 8 ). The effect of the impact varied from one (28.23\%) to five (3.23\%). The size reduction (19.35\%) affected farmers more than other single consequences of drought, as it accounted for more than two-thirds (68.54\%) of the single impact. Over one-quarter (28.32\%) of the two impacts were caused by the death of sheep and size reduction $(6.85 \%)$. Half of the farmers affected by three impacts were as a result of the reduction in offspring (calving), reduction in milk yield and size reduction while the death of sheep, reduction in offspring (calving), infertility in male sheep, and size reduction (7.66\%) were more disastrous among four impacts. However, the farmers affected by five impacts of drought were the least (3.23\%) of all the categories of drought impacts. Apart from the high rate of sheep death by drought in Nigeria, sheep death in other semi-arid areas in Africa including the $2.86 \%, 8.51 \%$, and $17.86 \%$ sheep deaths in Niger, Mali, and Burkina Faso, and 5.5\% of income in sheep losses due to deaths in Northern Tanzania have also been recorded (Oyekale, 2014; Ahmed et al., 2019). The exposure of ewes to high ambient temperatures during pregnancy damages fetal growth, reduces fetuses, and newborn lambs, causes brain sparing and intrauterine growth restriction in the newborn lambs and late gestation fetuses from heat-stressed ewes (De Vrijer et al., 2006; van Wettere et al., 2021). van Wettere et al. (2021) reported that the low birthweight lambs are more vulnerable to starvation-mismothering, hypothermia, and death. Premature deaths lead to lower future yields by limiting the reproductive capacity of the herd. 
Table 8

Nature of drought impact on Sheep in the Sokoto-Rima River Basin

$\begin{array}{lll}\text { S/N Sheep } & \begin{array}{l}\text { Number of } \\ \text { respondents }\end{array}\end{array}$

1 Death of sheep/Reduction in offspring (calving)/Reduction in 8

3.23 milk yield/Infertility in male sheep/Size reduction

2 Death of sheep/Reduction in offspring (calving)/Reduction in 2 milk yield/Infertility in male sheep

3 Death of sheep/Reduction in offspring (calving)/ Infertility in 19

Death of sheep/Reduction
male sheep/Size reduction

8

2

0.81

4 Death of sheep/Reduction in milk yield/Infertility in male sheep/Size reduction

19

7.66

5 Death of sheep/Reduction in offspring (calving)/Reduction in 8

milk yield/Size reduction

10

4.02

6 Reduction in offspring (calving)/Reduction in milk yield/Infertility in male sheep/Size reduction

7 Death of sheep /Reduction in offspring (calving)/Infertility in 2 male sheep

2

0.81

8 Death of sheep/Reduction in milk yield/Infertility in male sheep

9 Death of sheep/Reduction in offspring (calving)/Size reduction

6

2.42

3.23

10 Death of sheep/Reduction in milk yield/Size reduction

8

3.23

2

0.81

11 Death of sheep/Infertility in male sheep/Size reduction

7

2.82

12 Reduction in offspring (calving)/Reduction in milk yield/Size

28

11.29

reduction

13 Reduction in offspring (calving)/Infertility in male sheep/Size 4 reduction

4

1.61

14 Reduction in milk yield/Infertility in male sheep/Size reduction 1

15 Death of sheep/Reduction in offspring (calving)

2

0.40

16 Death of sheep/Reduction in milk yield

1

0.81

17 Death of sheep / Infertility in male sheep

3

0.40

18 Death of sheep/Size reduction

17

1.20

19 Reduction in offspring (calving)/Size reduction

14

6.85

20 Reduction in milk yield/Infertility in male sheep

1

5.64

21 Reduction in milk yield/Size reduction

8

0.40

3.23 


\begin{tabular}{|llll|}
\hline S/N & Sheep & $\begin{array}{l}\text { Number of } \\
\text { respondents }\end{array}$ & Percentage \\
\hline 22 & Infertility in male sheep/Size reduction & 14 & 5.65 \\
\hline 23 & Death of sheep & 20 & 8.06 \\
\hline 24 & Infertility in male sheep & 2 & 0.81 \\
\hline 25 & Size reduction & 48 & 19.35 \\
\hline & Total & 248 & 100 \\
\hline
\end{tabular}

The reduction in milk yield and/or poor milk yield is very high in the study area. Studies revealed that heat stress reduces milk production and its composition - the percentage of milk fat and proteins in particular but does not affect the content of lactose in milk (Zheng et al., 2009; Wheelock et al., 2010). The adverse effects of heat stress on spermatogenesis and semen quality in rams have been reported (Marai et al., 2008; Kastelic et al., 2017; Sawyer and Narayan, 2019). The occurrence of the best production of spermatozoa in rams requires testicular temperature below body temperature, and studies have shown the intra-testicular temperatures of 33 to $35^{\circ} \mathrm{C}$ in rams at ambient temperatures of 20 to $30^{\circ} \mathrm{C}$ (Coulter et al., 1988; Setchell, 1998). The high temperatures during the mating period harmfully affects fertilization, embryo survival, and pregnancy rates in the ewe (Kleemann and Walker, 2005). These problems were possibly responsible for the high rate of infertility in male sheep (Ram) in the study area.

Table 9 indicated the total individual drought impact on sheep in the Sokoto-Rima River Basin. The size reduction (83.87\%) affected sheep more than any other consequence of drought, which ranged from a reduction in milk yield (36.69\%) to the death of sheep (46.77\%) in the River Basin. The impact accounted for one-third of all the effects together. However, it was more than twice of reduction in milk yield, and infertility in Ram. The occurrence of the birth of under-sized weak lambs are prevalent during drought. Heat stress at this period affects the sheep reproduction, uterine environment, substantially reduces the total embryo cell number, placentae size resulting in a smaller size of lambs (Sawyer and Narayan, 2019; van Wettere et al., 2021).

Table 9

Total individual drought impact on sheep in the Sokoto-Rima River Basin

\begin{tabular}{|llll|}
\hline S/N & Drought impact & Number of respondents & Percentage \\
\hline 1 & Death of sheep & 116 & 46.77 \\
\hline 2 & Reduction in offspring (calving) & 110 & 44.35 \\
\hline 3 & Reduction in milk yield & 91 & 36.69 \\
\hline 4 & Infertility in male sheep (Ram) & 92 & 37.10 \\
\hline 5 & Size reduction & 208 & 83.87 \\
\hline
\end{tabular}




\section{Conclusion}

The study has shown that drought ravaged the study area during the period of the study. The drought constituted a major problem, that affects sheep breeds mostly during severe and extreme years in the study area. Balami was the most reared of the four breeds of sheep discovered. The occurrence of drought in the study area resulted in the change of sheep breed, majorly from Yankasa to Balami. The drought impact on sheep including the death of sheep, reduction in offspring (calving), reduction in milk yield, infertility in male sheep, and size reduction was generally high and detrimental to farmers sustenance. The size reduction was the greatest of the consequences.

The implication of drought on sheep includes reduced income, prized mutton and expensive dairy products. Effective drought planning including drought monitoring, proper irrigation management, and the establishment of water sources such as wells would be of help in cushioning the adverse effect of drought on sheep.

\section{Declarations}

\section{Conflict of interest}

The authors have read and understood the policy on declaration of interests and declare that there is no conflict of interest related to this article or legal bond or copyrights.

\section{Funding}

No funding is received from individuals, group, or any organization.

\section{Authors' contributions}

The research is the sole contribution of the author.

\section{Acknowledgements}

The author thanks the staff of the Nigerian Meteorological Agency and the farmers in the study area for the provision of data used in this study.

\section{References}

1. Adejuwon, J.0. 2015. An assessment of the changing pattern in the choice of vegetable varieties in Sokoto-Rima River Basin, Nigeria: Pepper. Int. J. Ecol. Env. Studies, 3(2): 7-15.

2. Adejuwon, J.O. 2016. Effect of Climate variability on school attendance: A case study of Zamfara State in the Semi-arid zone of Nigeria. Weather, 71 (10): 248-254. 
3. Adejuwon, J.0. 2019. Investigating agricultural calendar in a changing climate of the semi-arid Tropics. African Journal of Agriculture Technology and Environment, 8(1): 16-25

4. Adejuwon, J.O. and S.B. Olaniyan. 2019. Drought occurrence in the Sub-Humid Eco-Climatic Zone of Nigeria. J. Theor. Appl. Climatol., 137: 1625-1636. DOI 10.1007/s00704-018-2670-7.

5. Adu, I.F. and L.O. Ngere. 1979. The indigenous sheep of Nigeria. World Review of Animal Production, $15(3): 51-62$.

6. Ahmed, H. J., Yoder, W.A. de Glanville, A. Davis, T.J. Kibona, B.T. Mmbaga, F. Lankester, E.Swai and S. Cleaveland. (2019). Economic burden of livestock disease and drought in Northern Tanzania. J. Dev. Agric. Econ. 11(6): 140-151. DOI: 10.5897/JDAE2018.1028

7. Alary, V., S. Messad, A. Aboul-Naga, M. Osman, I. Daoud, P. Bonnet, X. Juanes and J.Tourrand, 2014. Livelihood strategies and the role of livestock in the processes of adaptation to drought in the Coastal Zone of Western Desert (Egypt). Agric. Syst., 128: 44-54.

8. Amankwah, K. Amankwah, L. Klerkx, S.J. Oosting, O.S. Dawson, A.J. Zijpp and D. Millar.Diagnosis constraints to the market participation of small ruminant producers in Northern Ghana: an innovation systems analysis. Wagener J Life Sci. 2012;60-63:37-47. Doi:

10.1016/j.njas.2012.06.002.

9. Australian Bureau of Agricultural and Resource Economics and Sciences (ABARES), 2011 Drought in Australia: Context, Policy, and Management, CC BY 3.0. Department of Agriculture, Fisheries, and Forestry.

10. Blench, R. and K.C. MacDonald. 1999. The Origins and Development of African Livestock. Routledge.

11. Budiansky, S. 1999. The Covenant of the Wild: Why animals chose domestication. Yale University Press.

12. Kastelic, J.P. Kastelic, R.E. Wilde, G. Rizzoto and J.C. Thundathil. 2017. Hyperthermia and not hypoxia may reduce sperm motility and morphology following testicular hyperthermia. Veterinární Medicína. 62: 437-442 https://doi.org/10.17221/124/2016-VETMED

13. Catley, A., B. Admassu, G. Bekele, D. Abebe. 2014. Livestock mortality in pastoralist herds in Ethiopia and implications for drought response. Disasters, 38: 500-516.

14. Chedid, M., L.S. Jaber, S. Giger-Reverdin, C. Duvaux-Ponter and S.K. Hamadeh, 2014. Review: Water stress in sheep raised under arid conditions. Canadian Journal of Animal Science. 94(2):243-257. DOI:10.4141/cjas2013-188

15. Coulter,G.H. P.L. Senger and D.R. Bailey. 1988. Relationship of scrotal surface temperature measured by infrared thermography to subcutaneous and deep testicular temperature in the ram. $J$ Reprod Fertility, 84(2): 417-423. https://doi.org/10.1530/jrf.0.0840417.

16. Dai, A. and National Center for Atmospheric Research Staff (Eds), last modified 12 Jul 2017. The Climate Data Guide: Palmer Drought Severity Index (PDSI).

"https://climatedataguide.ucar.edu/climatedata/palmer-drought-severity-index-pdsi"

17. Devereux, S., M. Rimmer, D. LeBeau and W. Pendleton. 1993. The 1992/3 Drought in Namibia: An evaluation of its socioeconomic impact on affected households. SSD Research Report 7. Windhoek, 
Namibia: Gamsberg Macmillan

18. De Vrijer, B., M.L. Davidsen, R.B. Wilkening, R.V. Anthony and T.R. Regnault. 2006. Altered placental and fetal expression of IGFs and IGF-binding proteins associated with intrauterine growth restriction in fetal sheep during early and mid-pregnancy. Pediatr. Res.,60:507-512. DOI:

10.1203/01.PDR.0000242364.78002.71.

19. Emielu, S.A. 2000. Senior Secondary Geography. Geographical Bureau Nigeria Limited, llorin. pp 7172.

20. Gibbs, W.J. and J.V. Maher. 1967. Rainfall Deciles as Drought Indicators. Commonwealth of Australia: Melbourne, Bureau of Meteorology Bulletin No. 48

21. Hiendleder, S., B. Kaupe, R. Wassmuth and A. Janke. 2002. Molecular analysis of wild and domestic sheep questions current nomenclature and provides evidence for domestication from two different subspecies. Proc. Biol. Sci. 269 (1494): 893.

22. Jones, S. 2014. Sheep and Goats. In: M. Hightower (Ed.) Drought Management and Recovery for Livestock System. Agriculture: Division of Research and Extension, University of Akansas, USA. MP530-PD-10-2014N https://www.uaex.edu/publications/pdf/mp530.pdf pp1-69

23. Kleemann, D.O. and S.K. Walker. 2005. Fertility in South Australian commercial Merino flocks: relationships between reproductive traits and environmental cues. Theriogenol. 3(9):2416-33. DOI: 10.1016/j.theriogenology.2004.09.052

24. Krishnan, G., M. Bagath, P. Pragna, M.K. Vidya, J. Aleena, P.R. Archana, V. Sejian and R. Bhatta. 2017. Mitigation of the heat stress impact in livestock reproduction. In: Carreira R.P., editor. Theriogenology. InTech International Publisher; Rijeka, Croatia (Accessed on 30 July 2021)]. p. 64e86. Available online: https://www.intechopen.com/books/theriogenology/mitigation-of-the-heatstress-impact-in-livestock-reproduction\#article-front.

25. Leite-Browning, M.L. 2016. Drought Management Strategies for Sheep and Goats. UNP-2112. The Alabama Cooperative Extension System (Alabama A and M University and Auburn University). https://ssl.acesag.auburn.edu > UNP-2112-archive

26. Marai, I.F.M., A.A. El- Daraany, A. Fadiel and M.A.M. Abdel-Hafez. 2008. Reproductive performance traits as affected by heat stress and its alleviation in sheep. Tropical Subtropical Agroecosyst. 8(3): 209-234. https://www.redalyc.org/pdf/939/93911235001.pdf

27.

28. Mason, I.L. 1988. A world dictionary of livestock breeds, types, and varieties. Third Edition, CAB International, Wallingford, UK.

29. Mijindadi, N.B. and J.O. Adegbehin. 1991. Drought, Desertification, and Food production in Nigeria. Savanna, 12 (2): 25-40

30. McKee, T.B. and N.J. Doesken and J. Kleist. 1993. The Relationship of Drought Frequency and Duration in Time Scales. Proceedings of the Eighth Conference on Applied Climatology. American Meteorological Society: Boston.

31. Mooney, H. and E. Zavaleta. 2016. Ecosystems of California. Univ of California Press, 1008p. 
32. Oboli, H.O.N. 1967. An Outline of West Africa. Harrap and Co. Ltd., London, 67-68, 115126. Ologunorisa, T.E. and J.O. Adejuwon. 2010. Inter-annual rainfall variability in the Niger Delta, Nigeria. The International Journal of Meteorology, 35 (345): 22-30

33. Oyekale, A.S. 2014. Impacts of Climate Change on Livestock Husbandry and Adaptation Options in the Arid Sahel Belt of West Africa: Evidence from a Baseline Survey. Asian Journal of Animal and Veterinary Advances, 9 (1): 13-26

34. Palmer, W.C. 1965. Palmer Meteorological drought. Weather Bureau Research Paper No. 45, U.S. Department of Commerce: Washington, D.C.

35. Resources Inventory and Management Limited (RIM), 1992. Nigerian Livestock Resources, Volume I: Small Ruminants. Report by Resources Inventory and Management Limited, U.K. to FDLPCS, Abuja, Nigeria

36. Salmoral, G., B. Ababio and I.P. Holman. 2020. Drought Impacts, Coping Responses and Adaptation in the UK Outdoor Livestock Sector: Insights to Increase Drought Resilience. MDPI, Basel, Switzerland

37. Sawyer and Narayan, 2019 G. M. Sawyer, E. J. Narayan A review on the influence of climate change on sheep reproduction. In E. J. Narayan (Ed.), Comparative Endocrinology of Animals (pp. 1-21). https://doi.org/10.5772/intechopen.86799

38. Setchell, B.P. 1998. The Parkes Lecture: Heat and the testis. J. Reprod. Fertility. 114(2):179-94 DOI: 10.1530/jrf.0.1140179. PMID: 10070346.

39. Theodor, J.M. 2001. Artiodactyla (Even-Toed Ungulates Including Sheep and Camels). John Wiley and Sons Ltd. https://doi.org/10.1038/npg.els.0001570

40. The Editors of Encyclopaedia Britannica, 2020. Sheep. Encyclopædia Britannica, Inc. https://www.britannica.com/animal/sheep. Accessed June 22, 2020.

41. van Wettere, W.H.E.J., K.L. Kind, K.L. Gatford, A.M. Swinbourne, S.T. Leu, P.T. Hayman, J.M. Kelly, A.C. Weaver, D.O. Kleemann and S.K. Walker. 2021. Review of the impact of heat stress on reproductive performance of sheep. J Animal Sci Biotechnol 12(1):26. https://doi.org/10.1186/s40104-02000537-z

42. Wheelock, J.B., R.P. Rhoads, M.J. Van Baale, S.R. Sanders and L.H. Baumgard. 2010. Effect of heat stress on energetic metabolism in lactating Holstein cows. Journal of Dairy Science 93(2): 644-655. 43.

44. Willeke, G., J.R.M Hosking, J.R. Wallis and N.B. Guttman. 1994. The national drought Atlas. Institute for Water Resources Report 94-NDS-4, U.S. Army Corps of Engineers.

45. World Meteorological Organization, 2012. Standardized Precipitation Index user guide. WMO-No. 1090 Geneva, Switzerland. http:// www.wamis.org/agm/pubs/SPI/WMO_1090_EN.pdf

46. Wu, H., M.J. Hayes, A. Welss and Q. Hu. 2001. An evaluation of the standardized precipitation index, the China-Z index, and the statistical Z-score. International Journal of Climatology 21: 745-758

47. Zheng, L., Zheng, M. Chenh and G. Zhi-Cheng. 2009. Effects of heat stress on milk performance and fatty acids in milk fat of Holstein dairy cows. Journal of China Dairy Industry 37(9): 17-19. 
Figures

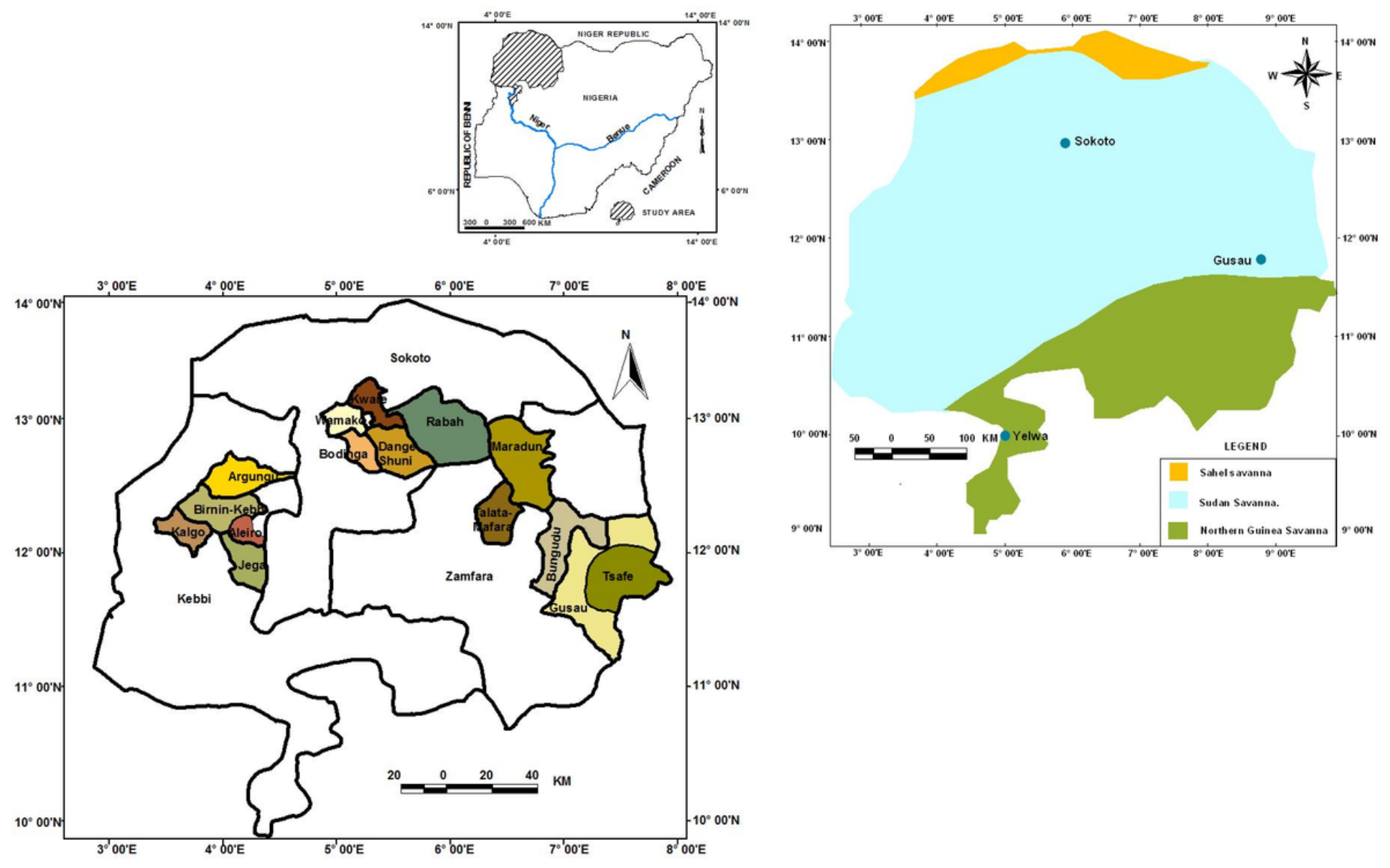

Figure 1

a: Selected local governments where questionnaire was administered. b. Major Vegetation types and study locations in Sokoto-Rima Rver Basin. 

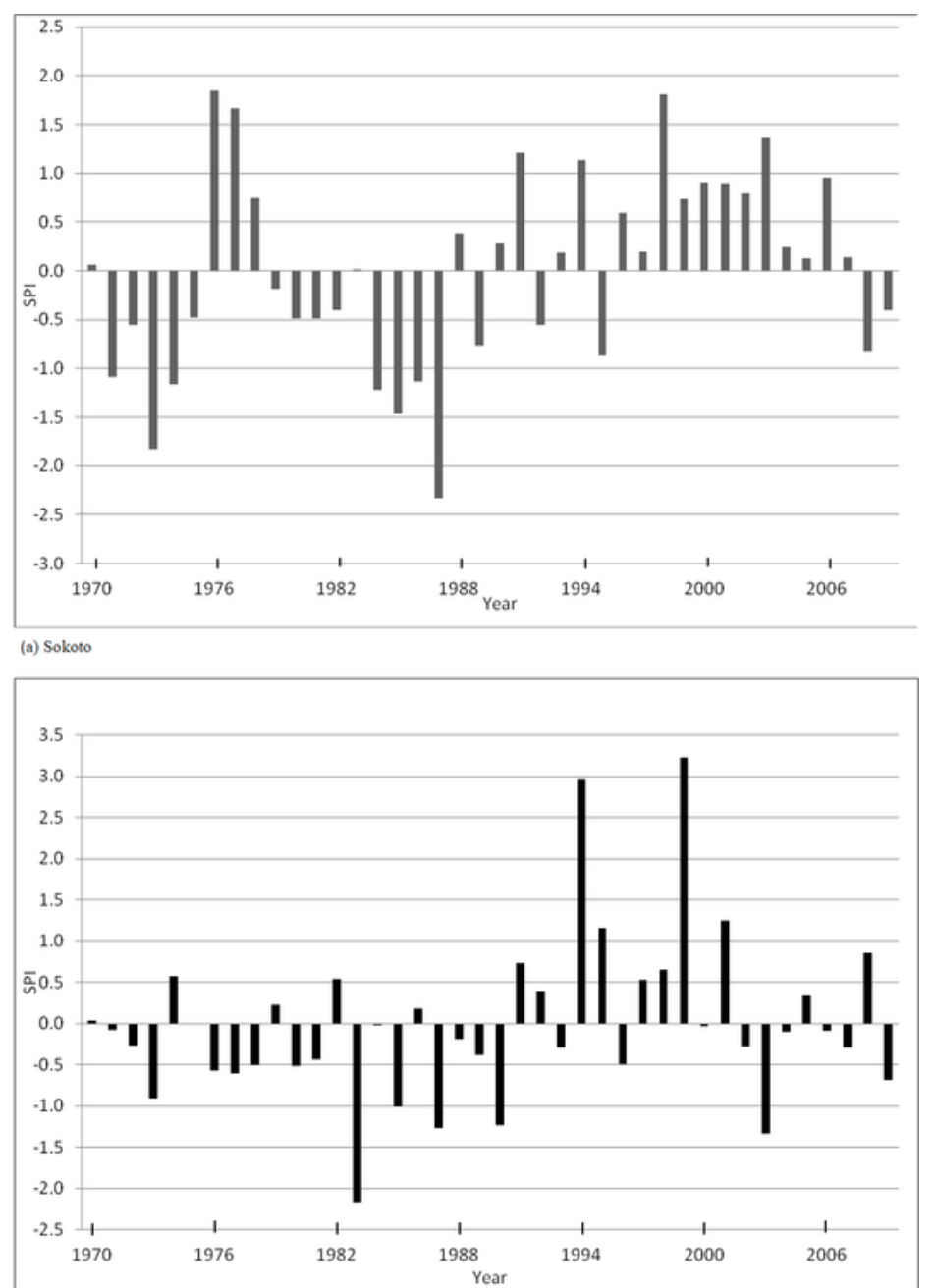

(b) Yelwa

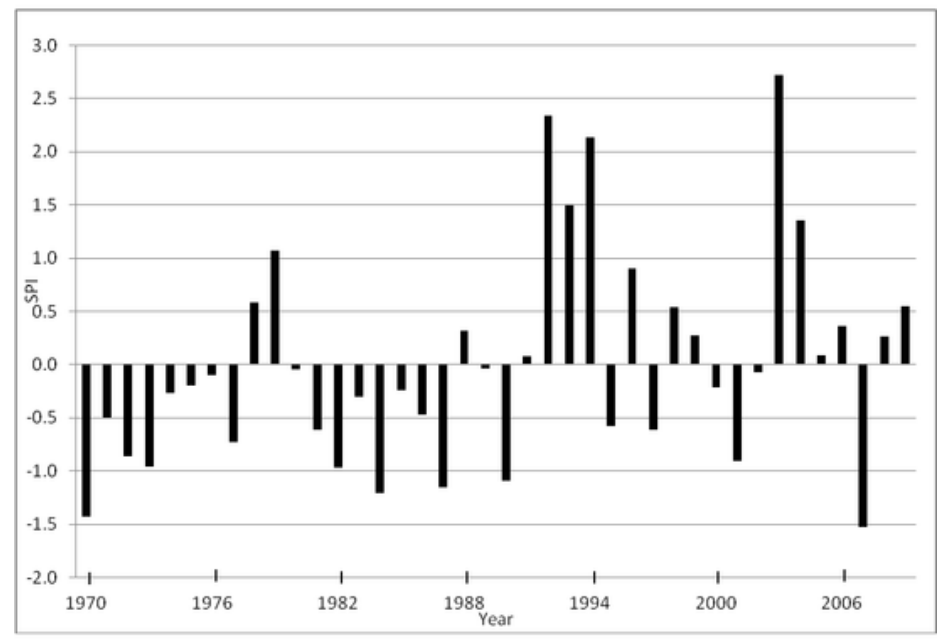

(c) Gusau

Figure 2

a-c Standardized Precipitation Index (SPI) showing drought duration and intensity in Sokoto-Rima River Basin 